\title{
Comparative assessment of the application of methods of regulating electricity and heat tariffs
}

\author{
Anna Minnullina ${ }^{1 *}$, Inessa Kosyakova ${ }^{2}$, Marina Chebykina ${ }^{3}$ and Nadezhda Skvortsova $^{4}$ \\ ${ }^{1,4}$ Industrial University of Tyumen, Volodarskogo str. 38, Tyumen, 625000, Russia \\ ${ }^{2}$ Samara State Technical University, Molodogvardeyskaya str. 244, Samara, Russia \\ ${ }^{3}$ Samara State University of economics, Solovetskoi Armii str. 141, Samara, Russia
}

\begin{abstract}
In the process of reviewing and approving electricity and heat tariffs, a power supply organization goes through several stages, one of which is the approval of the calculation method. In this regard, the article presents the results of the comparative assessment of application of several methods of regulating electricity and heat tariffs: a method of economically feasible costs (expenses); a method of indexing established tariffs; a return on invested capital method; a method of comparing analogues; a simplified calculation method. The results of calculations are analyzed and clearly reflected.
\end{abstract}

\section{Introduction}

Currently, tariff regulation in thermal power generationin Russia creates an incorrect system of incentives for market participants.

Inefficiency lies at the very heart of current regulation - a tariff is determined by regional energy commissions in accordance with the costs incurred by producers. At the same time, if aproducer made any improvements at its facility, completed the upgrading and could reduce production costs - in the next period of tariff regulation it risks losing all the savings that will be excluded from heat tariffs.

Certainly, in such conditions few producers decide to act at a loss to the company. The investment activity implies the possibility of returning the invested funds; however, it is absolutely impossible to do when cutting tariffs as a result of cost savings.

Another complex problem of the industry is cross-subsidization, which affects manufacturers working in the mode of combined electricity and heat generation and electricity consumers, who are forced to make double payment for electrical power from the wholesale market.

Due to the significant social aspect of thermal power generation, regional tariff commissions exclude part of the reasonable tariff of a combined heat and power (CHP) plantfor heat generation and transfer it to the electricity and power market, but at the same time, it is not possible to ensure the equivalence of this transfer.

At the same time, cheaper heat produced at CHP plants allows keeping the heat tariff for the end user within reasonable limits, since inefficient and expensive boiler houses

\footnotetext{
*Corresponding author: minnullinaay@yandex.ru
} 
constantly pull the tariff up.

The results of this policy are very disappointing:

more efficient and cost-effective CHP plants operating in the combined generation mode are currently mostly unprofitable due to the artificial lowering of tariffs and in recent years there is a clear tendency for their transition to the forced generation, which is the first signal of a possible subsequent closure;

inefficient and expensive boilerhouses feel quite comfortable and have no incentive to upgrade the equipment and reduce costs.

The typical difference in prices for thermal energy supplied by CHP plants and boiler houses is from $30 \%$ to $50 \%$.

The result of this policy is a tendency towards the development of boiler houses, which later, due to the closure of more cost-effective CHP plants, can lead to a very serious increase in tariffs.

Major industrial consumers are already moving towards using their own sources of generation, depriving the owners of generating facilities of a significant amount of income.

Measures to modernize inefficient and costly heat supply sources to ensure that the cost of their production is in line with accepted tariff levels should be further included in regional energy efficiency programs.

Fortum Corporation is one of the largest thermal energy producers in the world. Working in Northern Europe and the Baltic countries, the company has gained extensive experience in constructing efficient and reliable heating systems. In Russia, the corporation became the only foreign investor involved in the heat business and utilities.

Currently, Fortum PJSC, the Russian division of the corporation, is implementing a large-scale modernization of the heat supply infrastructure, which provides for the creation of new generating capacities based on cogeneration technologies, the integration of city heat sources for a more rational distribution of loads and the modernization of the heatingnetwork complex with the installation of individual heat points, metering devices on all borders.

The company's management assumes that increasing the efficiency of the entire heating system will allow fixing, and, in some cases, reducing the tariff burden on residents. But in order to support heat supply system modernization projects it is necessary to improve the institutional environment: elimination of all types of cross-subsidies, early adoption of regulatory acts that encourage market participants to invest in the development of heat sources and heat networks, and introduction of anti-discrimination measures with respect to CHP plants in the wholesale electricity and power market.

The international experience of the company is used for the development of cogeneration in the regions of Russia for solving a number of relevant industry problems: - tosignificantly increase the efficiency of production of both thermal and electric energy; - to reduce the prospective tariff burden on electricity consumers through the construction of sources in the immediate vicinity of consumption nodes;

- tosearch for an effective direction for the development of generation that does not require additional tariff burden for the end user.

Certainly, there are many problems in electricity and heat tariffing, but the state and energy companies direct all efforts and opportunities to solve them, so that all the necessary expenses are not passed on to the consumer through tariffs and, at the same time, the level of profit does not decline.

The works of many Russian scholars are devoted to problems of managing electricity and heat tariffs: V. Anufriev, L. Bogachkova, A. Vigdorchik, N. Vilensky, V. Vershinin, L. Gitelman, R. Zaripov, A. Zlatopolsky, Yu. Klyuev, Yu. Kogan, A. Karyakin, V. Okorokov, R. Okorokov, S. Pruzner, V. Proskuryakov, R.Samuilavičius, B. Ratnikov, M. Styrikovich, Yu. Savenko, M. Fedorov, V. Shelest, E. Steinhaus, D. Kazum, G. Saunders, K.M. Meyer- 
Abikh, H. Meixner, G. Saunders, U. Haampike, etc. [1-8]

\section{Methods}

Tariff as a cost per service unitreconciles the interests of suppliers and consumers. If the balance of interests of sellers and buyers is not ensured for various objective and subjective reasons, the intervention of state regulatory bodies is necessary. Changes in the cost of heat and electricity generation have the greatest impact on the value of tariffs. The dynamics of changes in energy tariffs of the CHP plant for Fortum PJSC is given in Table 1.

Table 1. Dynamics of changes in electricity tariffs of the CHP plant

\begin{tabular}{|l|c|c|c|}
\hline \multirow{2}{*}{ Indicators } & \multicolumn{3}{c|}{ Values by years } \\
\cline { 2 - 4 } & 2016 & 2017 & 2018 \\
\hline Costs of electricity generation and sale (thousand euros) & 324726.2 & 393389.4 & 422555.1 \\
\hline Costs of heat generation and sale (thousand euros) & 127550.2 & 139944.6 & 152413.7 \\
\hline Electricity tariff rate without VAT (euros/ $\mathrm{kWh})$ & 0.026 & 0.028 & 0.031 \\
\hline Heat tariff rate without VAT(euros/Gcal.) & 5.8 & 6.5 & 8.3 \\
\hline
\end{tabular}

As can be seen from Table 1, there is a direct connection between the costs of energy generation and the established tariffs, i.e. if the costs of an enterprise increase, the rate of energy tariff increases, so the growth rate of electricity generation costs in 2018 compared to 2016 was $30.1 \%$, and the growth rate of the tariff for three years was $45.6 \%$; the cost of heat generation increased by $19.4 \%$, and the tariff for the same type of energy increased by $11.2 \%$. This is due to the fact that in addition to the production costs, the cost of transportation of this type of energy to the consumer is also included in the amount of the tariff.

In the process of reviewing and approving tariffs for electrical energy (power) and heat energy (power), the energy supply organization submits to the REC the proposals for the approval of electricityand heat energy tariffs, including:

- determination (economic justification) of the total financial need in funds (cost and profit) for the regulated activities for the regulatory period;

- determination of the types and volumes of services in kind, supplied by the energy supply organization to consumers for regulated activities;

- distribution of the total need for financial resources (cost and profit) among the types of products for regulated activities;

- calculation of tariffs (amount of payment for services): average tariff for an energy supply organization and for groups (categories) of consumers.

Based on the results of review of the materials submitted by an energy supply organization, the Regional Commission approves tariffs for electricity and heat energy by consumer categories in the region served by this energy supply organization.

Single-rate tariffs (prices) for both electricity and heat energy supplied to consumers are the sum of components calculated by an organization, based on the technological features of energy generation and sale to the consumer, they are shown schematically in Figure 1.

Table 2. Scheme of formation of one-rate tariff

\begin{tabular}{|c|c|}
\hline \multicolumn{2}{|c|}{ Electricity and heat tariffs (prices) } \\
\hline \multirow{2}{*}{$\begin{array}{c}\text { «+»average cost of a unit of electrical (heat) } \\
\text { energy }\end{array}$} & «+»total cost of energy transmission services \\
\hline
\end{tabular}




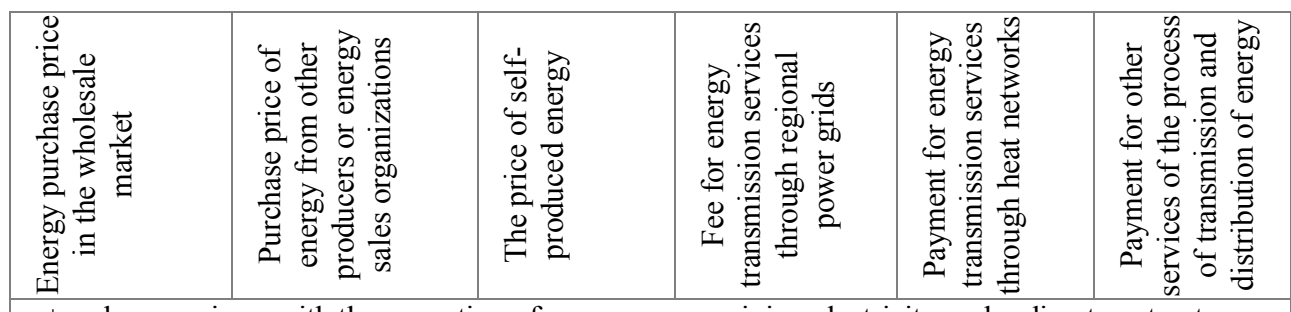

«+»ssales premium, with the exception of consumers receiving electricity under direct contracts «+»subscription fee, with the exception of consumers - subjects of the wholesale electricity market

An electricity and heat tariff is a regulator of the market. If the buyer is satisfied with the price and he/she bought the product, this means that the buyer "recognized" the efforts and costs of the manufacturer as "justified" and the balance of supply and demand was established in the market.

As a result of the analysis of various scientific works [2,3,4,6,8,9,10] devoted to the issues of tariffication in the field of heat and electricity, a set of tariff regulation methods has been formed:

1) method of economically feasible costs (expenses);

2) method of indexing established tariffs;

3) return oninvested capital method;

4) method of comparing analogues;

5) simplified calculation method.

In general, all the advantages and disadvantages of the above tariff adjustment methods can be summarized in summary table 3 .

Table 3. Advantages and disadvantages of tariff adjustment methods

\begin{tabular}{|l|l|l|}
\hline \multicolumn{1}{|c|}{ Method } & \multicolumn{1}{|c|}{ Advantages } & \multicolumn{1}{c|}{ Disadvantages } \\
\hline $\begin{array}{l}\text { Method of } \\
\text { economically } \\
\text { feasible costs } \\
\text { (expenses) }\end{array}$ & $\begin{array}{l}\text { 1. The tariff provides the } \\
\text { company the opportunity of } \\
\text { break-evenfunctioning } \\
\text { 2. The company receivesreturn } \\
\text { on invested capital }\end{array}$ & $\begin{array}{l}\text { 1. Encouraging overinvestment (Averch- } \\
\text { Jones effect) } \\
\text { 2. There are no significant incentives to } \\
\text { improve the efficiency of service delivery. } \\
\text { 3. The regulatory procedure requires time- } \\
\text { consuming and financial resources, because } \\
\text { there is the need to check the cost information } \\
\text { submitted by enterprises that is associated } \\
\text { with attracting external experts (auditors, } \\
\text { engineers, etc.) }\end{array}$ \\
\hline $\begin{array}{l}\text { Method of } \\
\text { indexing } \\
\text { established } \\
\text { tariffs }\end{array}$ & $\begin{array}{l}\text { With cost savings compared to } \\
\text { the base level of tariffs, the } \\
\text { resulting savings can } \\
\text { automatically remain in the } \\
\text { company. }\end{array}$ & $\begin{array}{l}\text { Organizations can voluntarily return to the } \\
\text { cost method and withdraw all the resulting } \\
\text { savingsat any time. }\end{array}$ \\
\hline $\begin{array}{l}\text { Return on } \\
\text { invested } \\
\text { capital } \\
\text { method }\end{array}$ & $\begin{array}{l}\text { By investing attracted } \\
\text { investments in the repair, } \\
\text { reconstruction and } \\
\text { modernization of power } \\
\text { equipment, the power system } \\
\text { can be brought to a new level. }\end{array}$ & $\begin{array}{l}\text { By increasing investments there is a risk of an } \\
\text { increase in the heat and electricity tariff }\end{array}$ \\
\hline
\end{tabular}




\begin{tabular}{|l|l|l|}
\hline \multicolumn{1}{|c|}{ Method } & \multicolumn{1}{c|}{ Advantages } & \multicolumn{1}{c|}{ Disadvantages } \\
\hline $\begin{array}{l}\text { Method of } \\
\text { comparing } \\
\text { analogues }\end{array}$ & $\begin{array}{l}\text { The method of comparing } \\
\text { analogues allows identifying the } \\
\text { way a particular company is } \\
\text { overvalued or underestimated } \\
\text { (rapid assessment) compared } \\
\text { with analogous ones. }\end{array}$ & $\begin{array}{l}\text { 1. It is often difficult (and hardly justified) to } \\
\text { compare the indicators of a regulated } \\
\text { company with a "benchmark" due to } \\
\text { significant differences in operating conditions } \\
\text { and starting conditions for the efficiency of } \\
\text { the compared companies, and it is also } \\
\text { difficult to adequately amend the calculation } \\
\text { data that take into account these differences; } \\
\text { 2. There is a risk of collusion between the } \\
\text { companies being compared, making it } \\
\text { difficult for the regulatory body to conduct an } \\
\text { objective comparative analysis of their } \\
\text { effectiveness. }\end{array}$ \\
\hline $\begin{array}{l}\text { Simplified } \\
\text { calculation } \\
\text { method }\end{array}$ & $\begin{array}{l}\text { The method is simple in } \\
\text { calculations, there is no need to } \\
\text { know the technical details of } \\
\text { energy generation, only } \\
\text { accounting reports are enough. }\end{array}$ & $\begin{array}{l}\text { The mothe into account such } \\
\text { factors as the length of networks, the number } \\
\text { of hours of energy supply, the technical } \\
\text { condition of networks and the cost of paying } \\
\text { for the loss of energy products. }\end{array}$ \\
\hline
\end{tabular}

Thus, regulatory bodies have different tools for the tariff system construction, and regional and local authorities have to decide how to use them.

\section{Results}

Today, almost all energy supply organizations use the method of economically sound tariffs to determine the required energy tariff rate, but it is also necessary to single out four more methods that were considered above, for determining the tariff.

In determining the feasibility of the practical application of one of the considered methods, a comparative analysis of the results of tariff rate calculation was carried out. [1112]

1. Method of economically feasible costs.

This method provides for the inclusion in the amount of the tariff all elements of the costs used by the company for energy generation. All the necessary data for calculating the electricity tariff is summarized in Table 4.

Table 4. Source data for calculation of the electricity tariff for the period of 2016-2018

\begin{tabular}{|l|c|c|c|c|c|c|c|}
\hline \multirow{2}{*}{ Indicators } & \multirow{2}{*}{ Symbol } & \multicolumn{3}{|c|}{ Years } & \multicolumn{3}{c|}{ Growth rate, \% } \\
\cline { 3 - 8 } & & 2016 & 2017 & 2018 & $\begin{array}{c}2017 \\
/ 2016\end{array}$ & $\begin{array}{c}2018 / 2017 \\
2018 /\end{array}$ & \begin{tabular}{c}
2016 \\
\hline
\end{tabular} \\
\hline $\begin{array}{l}\text { Required gross revenue } \\
\text { (thousand euros) }\end{array}$ & $\mathrm{RGR}$ & 399054.8 & 486912.2 & 544985.1 & 1.7 & 1.6 & 1.9 \\
\hline $\begin{array}{l}\text { Power supply to the } \\
\text { networks of the appropriate } \\
\text { voltage level (mln kWh) }\end{array}$ & $N_{i}^{\text {sup }}$ & 18.794 & 20.516 & 23.404 & 109.2 & 114.1 & 124.5 \\
\hline $\begin{array}{l}\text { Number of hours of power } \\
\text { use (h/year) }\end{array}$ & $\mathrm{h}_{\mathrm{i}}$ & 6800 & 7100 & 7300 & 104.4 & 102.8 & 107.4 \\
\hline $\begin{array}{l}\text { Calculated electric power } \\
\text { loss (mln kWh) }\end{array}$ & & 1.128 & 1.171 & 1.368 & 103.8 & 116.8 & 121.3 \\
\hline $\begin{array}{l}\text { Costs of payment for energy } \\
\text { losses (euros/kWh) }\end{array}$ & $\mathrm{I}_{\mathrm{i}}^{\text {cons }}$ & 0,02 & 0,02 & 0,02 & 1,53 & 1,46 & 1,61 \\
\hline $\begin{array}{l}\text { Total plannedelectricity } \\
\text { supply (mln. kWh) }\end{array}$ & $E_{i}^{\text {sup }}$ & 24.105 & 25.249 & 26.047 & 104.7 & 103.2 & 108.1 \\
\hline Standards of technical & $\alpha_{\mathrm{i}}$ & 6.1 & 6.8 & 7.1 & 111.5 & 104.4 & 116.4 \\
\hline
\end{tabular}




\begin{tabular}{|l|c|c|c|c|c|c|c|}
\hline losses of electricity (\%) & & & & & & & \\
\hline $\begin{array}{l}\text { Obtained electricity tariff } \\
\text { rate (euros/kWh) }\end{array}$ & $T_{i}$ & 0,03 & 0,03 & 0,03 & 1,53 & 1,50 & 1,65 \\
\hline
\end{tabular}

According to Table 4, it can be seen that the growth rate of the required gross revenue is higher than that of the calculated tariff, for example, for three years the growth rate of RGR was $36.6 \%$ and the tariff growth was $18.8 \%$. This is due to the fact that in addition to RGR, the amount of the tariff also includes the cost of energy transportation to the consumer and, in turn, it is affected by the amount of energy supplied; all these elements of costs are included in the tariff calculation when applying the method of economically feasible costs.

2. Method of indexing established tariffs

To calculate the electricity tariff by the indexing method, it is necessary to know the actual value of the tariff in 2015 (it amounts to 0.02 euros $/ \mathrm{kWh}$ ). Using the index of prices (growth of regulated tariffs and market prices) for electricity for all categories of consumers, the expected electricity tariff rate needs to be calculated (Table 5).

Table 5. Calculation of the electricity tariff by using the indexing method

\begin{tabular}{|l|c|c|c|c|}
\hline \multicolumn{1}{|c|}{ Values } & \multicolumn{4}{c|}{ Years } \\
\cline { 2 - 5 } & 2015 & 2016 & 2017 & 2018 \\
\hline Price index (\%) & & 5.7 & 13.1 & 11.3 \\
\hline Electricity tariff rate (euros/kWh) & 0,02 & 0,02 & 0,02 & 0,03 \\
\hline
\end{tabular}

According to Table 5, the tariff rate calculated by the indexing method is less than the actual value of the tariff. This is due to the fact that the indexing method does not take into account various factors affecting the increase in the tariff of an energy supply organization, for example, such as: investment policy; an increase in accounts receivable of an organization; i.e. this method does not take into account any internal problems of a company that needs to be included in the tariff, for the balance of costs and revenues.

3.Return on invested capital method (RAB)

In this method, in order to cover costs and set the tariff, the required gross revenue (RGR) after energy generationis calculated as the sum of the company's production costs, income on invested capital and return on invested capital. The adjustment of RGR to actual indicators and the adjustment in order to smooth the tariff are not significant for understanding the basic principle of RGRformation and they can be neglected when considering the problem, especially whenforecasting a change inRGR the predicted and "actual" indicators are obviously identical.

The necessary indicators for tariff calculation by using the return on invested capital method are summarized in Table 6.

Table 6. Data for calculating the electricity tariff by using RAB method

\begin{tabular}{|c|c|c|c|}
\hline \multirow[t]{2}{*}{ Indicators } & \multicolumn{3}{|c|}{ Years } \\
\hline & 2016 & 2017 & 2018 \\
\hline The costs associated with energy production $\left(\mathrm{I}_{\mathrm{t}}\right)$ & 324726,17 & 393389,44 & 422555,14 \\
\hline $\begin{array}{l}\text { The amount of invested capital in the long-term } \\
\text { regulatory period }\left(\mathrm{K}_{1}\right) \text { (thousand euros) }\end{array}$ & 227134,69 & 203982,00 & 205130,01 \\
\hline The period recovery of invested capital $\left(\mathrm{T}_{\mathrm{r}}\right)$ (years) & 35 & 35 & 35 \\
\hline Physical depreciation of invested capital $\left(\mathrm{IC}_{1}\right)(\%)$ & 27 & 32 & 37.5 \\
\hline Capital amortization (return) $\left(\mathrm{A}_{\mathrm{t}}\right)$ (thousand euros) & 122638,44 & 148325,51 & 203924,71 \\
\hline $\begin{array}{l}\text { Sum of the values of investments provided for by } \\
\left.\text { the investment program for the entire period ( } \mathrm{I}_{t}\right) \\
\text { (thousand euros) }\end{array}$ & 18178,47 & 18178,47 & 18178,47 \\
\hline The value of net working capital (NWC) (thousand & 68615,47 & 107152,11 & 216120,69 \\
\hline
\end{tabular}




\begin{tabular}{|l|c|c|c|}
\hline \multirow{2}{*}{ Indicators } & \multicolumn{3}{c|}{ Years } \\
\cline { 2 - 4 } & 2016 & 2017 & 2018 \\
\hline euros) & & & \\
\hline Recovery of invested capital $\left(\mathrm{RC}_{\mathrm{t}}\right)$ (thousand euros) & 32441,25 & 35319,82 & 36933,22 \\
\hline Return on investment $\left(\mathrm{RI}_{\mathrm{t}}\right)($ thousand euros) & 61073,75 & 82442,60 & 149346,72 \\
\hline Required gross revenue $\left(\mathrm{RGR}_{\mathrm{t}}\right)($ thousand euros) & 418241,18 & 511151,86 & 608835,08 \\
\hline Obtainedelectricity tariff rate (euros/kWh) & 0,03 & 0,04 & 0,04 \\
\hline
\end{tabular}

Electricity tariff rate is calculated as follows - 0.04 euros $/ \mathrm{kWh}$ and $23404(\mathrm{mln} \mathrm{kWh})-$ the power supplied to the networks of the corresponding voltage level, and 7300 (h/year) the number of hours of power use.

According to the results of Table 6, it is clear that the required gross revenue calculated by the return on invested capital method is greater than that calculated by the method of economically feasible costs; this is due to the fact that in this method the company's investment costs, the cost ofinvestment in its own fixed assets are included in the amount of RGR.

4. Simplified method of tariff rate calculation

This method determines the electricity tariff rate by simply dividing the sum of the cost and profit of an organization from the sale of products by the actual generation of the energy produced. All the necessary data for the tariff rate calculation by using this method are summarized in Table 7.

Table 7. Calculation of the heat and electricity tariff by the simplified method

\begin{tabular}{|l|c|c|c|c|c|c|}
\hline \multirow{2}{*}{\multicolumn{1}{c|}{ Indicators }} & \multicolumn{4}{|c|}{ Years } & \multicolumn{3}{c|}{ Growth rate, \% } \\
\cline { 2 - 7 } & 2016 & 2017 & 2018 & $\begin{array}{c}2017 \\
/ 2016\end{array}$ & $\begin{array}{c}2018 / 2 \\
2017\end{array}$ & $\begin{array}{c}2018 / \\
2016\end{array}$ \\
\hline $\begin{array}{l}\text { Cost of electricity production } \\
\text { (thousand euros) }\end{array}$ & 324726,17 & 393389,44 & 422555,14 & 121.1 & 107.4 & 130.1 \\
\hline $\begin{array}{l}\text { Balance profit from electricity } \\
\text { (thousand euros) }\end{array}$ & 45226,13 & 62506,18 & 98362,68 & 138.2 & 157.4 & 217.5 \\
\hline $\begin{array}{l}\text { Electricity generation } \\
\text { (millionkWh) }\end{array}$ & 18.794 & 19.516 & 23.404 & 103.8 & 119.9 & 124.5 \\
\hline $\begin{array}{l}\text { Electricity tariff rate } \\
\text { (euros/kWh) }\end{array}$ & 0,02 & 0,02 & 0,02 & 113.5 & 111.3 & 126.2 \\
\hline
\end{tabular}

According to the table, there is a steady increase in the electricity tariff, which is logical and can be explained by the increase in the cost of generating this type of energy; for example, by 2018 the electricity tariff increased by $26.2 \%$ compared to 2016 .

In order to determine which method is the most economical, we conducted a comparative analysis of the above methods of calculation of the tariff rate of electricitygeneration and sale and presented the resultsin Table 8.

Table 8. Summary of calculation of electricity tariffs

\begin{tabular}{|c|l|c|c|c|}
\hline Line & \multicolumn{1}{|c|}{ Methods } & $\mathbf{2 0 1 6}$ & $\mathbf{2 0 1 7}$ & $\mathbf{2 0 1 8}$ \\
\hline 1 & $\begin{array}{l}\text { Actual single-rate tariff set by the Regional Energy } \\
\text { Commission }\end{array}$ & 0.03 & 0.03 & 0.03 \\
\hline 2 & Method of economically feasible costs & 0.03 & 0.03 & 0.03 \\
\hline 3 & Line 2 / line 1 (\%) & 4.2 & 5.9 & 5.9 \\
\hline 4 & Method of indexing established tariffs & 0.02 & 0.02 & 0.03 \\
\hline 5 & Line 4 / line 1 (\%) & -23.3 & -20 & -17.2 \\
\hline 6 & Return on invested capital method & 0.03 & 0,04 & 0.04 \\
\hline 7 & Line 6 / line 1 (\%) & 24.3 & 22.9 & 16.3 \\
\hline 8 & Simplifiedmethod & 0.02 & 0.02 & 0.02 \\
\hline
\end{tabular}




\begin{tabular}{|c|l|c|c|c|}
\hline Line & \multicolumn{1}{|c|}{ Methods } & $\mathbf{2 0 1 6}$ & $\mathbf{2 0 1 7}$ & $\mathbf{2 0 1 8}$ \\
\hline 9 & Line 8/ line 1 (\%) & -25.4 & -21.9 & -19.5 \\
\hline 10 & $\begin{array}{l}\text { The minimum value of the results of calculation of } \\
\text { electricity tariffs }\end{array}$ & 0.02 & 0.02 & 0.02 \\
\hline
\end{tabular}

Data of Table 8 indicate that the most minimal electricity tariff rates are calculated by the simplified method. This is explained by the fact that this method does not take into account many financial, economic and production factors that are laid down by an energy supply organization in the amount of the tariff, for example: the number of hours of power use; expenses for electricity losses; a coefficient of growth in prices for resources; invested capital; depreciation of invested capital; required gross revenue; i.e. this method takes into account only the cost of energy generated, the profit obtained from the sale of power and the actual output, which explains the simplicity of the calculation.

The most expensive method of tariff determination is a return on invested capital method. For an average of three years, the tariff calculated by this method exceeded the actual value of the tariff by $21.2 \%$.

The dynamics and levels of tariff rates calculated by various methods can be visually traced in Figure 2.

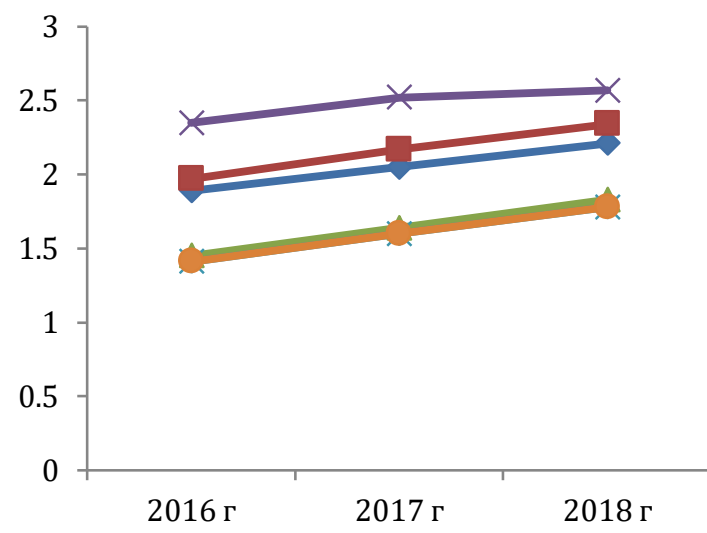

Actual single-rate tariff set by the Regional Energy Commission

-Method of economically feasible costs

$\longrightarrow$ Method of indexing established tariffs

$*$ Return on invested capital method

* Simplifiedmethod

Fig. 3. Dynamics of electricity tariff rates

\section{Conclusions}

The results of the comparative assessment ofcalculation of electricity and heat tariff rates by various methods indicate that the most economical method for determining the electricity tariff is a simplified calculation method, but "economical" does not mean suitable, this method showed the lowest values of the electricity tariff (in $2018-0.02$ euros $/ \mathrm{kWh}$ ). However, this method does not take into account other significant economic and production factors that also need to be included in the costs for determining the tariff. The return on invested capital method is the most time-consuming and cost-intensive method for determining the tariff.

Thus, regulatory bodies have significant tools for the tariff system construction, and regional and local authorities have to decide how to use them. As the actual analysis has shown, the choice has already been made at the local level - this is a method of economically feasible costs that balances the interests of energy consumers and producers in a quite possible way. 


\section{References}

1. L. Gitelman, B. E. Ratnikov, Efficient power company: Economy. Management. Reforming (ZAO Olimp-Business, Russia 2013)

2. K. Menar, Contracts and costs in the resource-supply sub-sectors of housing and communal services (TEIS, Russia 2012)

3. L. Melamed, Energy Economics: Foundations of Theory (SB RAS, Russia 2011)

4. B. Papkov, Electricity Market and Tariffs (Nizhny Novgorod State Technical University, Nizhny Novgorod, 2010)

5. V. Lelekov, Organization of production and management at generating enterprises of modern energy of Russia (MGOU, Russia 2011)

6. V. G. Kpeiner, Legislative support of reforms in the energy sector, 2, p.108-114 (2010)

7. L. A. Korshunova, N. G. Kuzmina, E. V. Kuzmina, Tariff formation for the transmission and distribution of electric energy in Russia, 4, p.46-49 (2011)

8. M. S. Berner, Using the investment component in the tariffs for products of natural monopolies, Energy Manager, 23, p.40-56 (2013)

9. D. Izvin, V. Lez'Er, A. Kopytova, MATEC Web of Conferences, 170, 01065 (2018) doi: $10.1051 /$ matecconf $/ 201817001065$

10. A. Yu. Minnullina, Economics, 8(57), p.307-311 (2009)

11. A. Yu. Minnullina, Modern problems of management: a collection of materials of the All-Russian scientific and practical, 5, p.97-102 (2015)

12. A. Minnullina, V. Vasiliev, E3S Web of Conferences 33, 03060 (2018), doi:10.1051/e3sconf/20183303060 